Boletín de la Sociedad Geológica Mexicana

VOLUMEN 61, NÚM. 2, 2009, P. 177-183

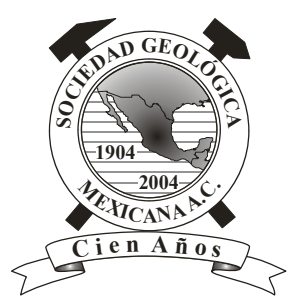

\title{
Palaeometry: Non-destructive analysis of fossil materials
}

\author{
Francisco Riquelme ${ }^{1, *}$, José Luis Ruvalcaba-Sil ${ }^{2}$, Jesús Alvarado-Ortega ${ }^{1}$ \\ ${ }^{1}$ Instituto de Geología, Universidad Nacional Autónoma de México. Circuito de la Investigación S/N, Ciudad Universitaria, \\ Delegación Coyoacán, D.F., 04510, México. \\ ${ }^{2}$ Instituto de Física, Universidad Nacional Autónoma de México, México, Apartado postal 20-364, Mexico, D.F. 01000. \\ * riquelme.fc@gmail.com
}

\begin{abstract}
Palaeometry involves the combined use of different non-destructive analytical techniques on the study of fossil and subfossil materials. This work reports the results of the first Palaeometric analysis using Visible Fluorescence Induced by the UV-Light and PIXE (Particle Induced X-ray Emission spectrometry) applied on fossil samples from Tlayúa quarry, Mexico (Tlayúa Formation, Early Cretaceous, Albian). This paper provides a short discussion on the results implications for the understanding of the fossilization process occurred on Tlayúa. Also, results suggest the presence of characteristic fossil fingerprints for the exceptional preservation of fossils for this Konservat-Lagerstätte, determined by the contents of elements such as Calcium, Phosphorus, Manganese, Iron and Arsenic.
\end{abstract}

Keywords: Fluorescence inducted by UV-Light, PIXE, Tlayúa, Konservat-Lagerstätte.

\section{Resumen}

La Paleometría involucra el uso combinado de distintas técnicas analiticas no-destructivas para el estudio de materiales de naturaleza fósil y subfósil. En este trabajo se presentan los resultados del primer estudio de Paleometría, usando Fluorescencia de Luz Visible Inducida por Luz UV y la Espectroscopía de Emisión de Rayos X Inducida por Partículas (PIXE), aplicado a muestras de la Cantera Tlayúa, México (Formación Tlayúa, Cretácico temprano, Albiano). También se presenta una breve discusión sobre las implicaciones de estos trabajos para un mejor entendimiento del proceso de fosilización ocurrido en Tlayúa. La información obtenida sugiere la presencia de fingerprints fósiles característicos de la preservación excepcional para esta Konservat-Lagerstätte, dados por los contenidos de elementos como Calcio, Fósforo, Manganeso, Hierro y Arsénico.

Palabras clave: Fluorescencia Inducida por Luz UV, PIXE, Tlayúa, Konservat-Lagerstätte. 


\section{Introduction}

Palaeometry of fossil material involves analytical aspects from imaging of the specimen using various light wavelengths for modeling (virtual imaging) to elemental micro-mapping (mineral and isotopic phases), as well as teledetection in the quarry, without any damage or alteration to the fossil material or its rock matrix. The techniques included into Palaeometry are described within the Molecular Palaeobiology (Briggs, 2003; Peterson et al., 2007; and Raffa et al., 2008; among others). The research on Palaeometry covers a broad range of organisms and several statigraphical levels; it has a multidisciplinary point of view including basic aspects from biological, earth, and chemical sciences. The research on Palaeometry includes palaeogeophysic prospecting, development of virtual models and compositional analysis of fossil specimens, in order to understand their original source, biological structures and particular properties of mechanisms of preservation. These techniques and methods help to solve questions of field's work (teledetection of fossil deposits) and laboratory (identify micro-morphologies and process of fossil preservation). The good results obtained so far throughout the Palaeometry include a large amount of valuable information that it is being used successfully in multidisciplinary areas that require to generate a large amount of accurate data; some of this areas are: Exobiology, Geomicrobiology, Archaeometry, Geobiology, Physical Anthropology and Forensics Sciences. This paper shows the results of the research on the chemical composition of fossils from Tlayúa through a powerful non-destructive analysis that includes the combined ion beam techniques using electrostatic accelerators and images generated by Visible Fluorescence Induced by UV-light.

Ion beam techniques based on electrostatic accelerators are non-invasive, high elemental sensitive, and powerful for multielemental quantitative analysis (Johansson et al., 1995; Ruvalcaba-Sil, 2002; Tsuji et al., 2004), in particular these techniques are significantly helpful to recognize the characteristic trace elements on organic matters and geochemical fingerprints with the goal to generate outstanding information about biological origin, environmental fluctuations and diagenetic alterations (Riquelme, 2009; Ruvalcaba-Sil, 2002).

On the other hand, the images generated through the Visible Fluorescence Induced by UV-light constitute a useful tool for fossil examination because this technique shows impressive and fine details of morphology (Tischlinger and Frey, 2002). Additionally, it is a diagnostic tool because produce a preliminary images of the biogeochemical state of fossil (Riquelme et al., 2009). The light emitted from samples under UV technique changes as a function of the chemical composition of the sample (Buzit-Tragni, 2005); therefore this technique shows also the degree of chemical heterogeneity of the fossils and its matrix and it facilitates the selection of points of analysis on the samples with other more accurate analytical methods. Recently the UV-light has been successfully applied on taxonomic studies of fossils in order to identify anatomic parts that are not recognizable under classic photographic techniques (Tischlinger and Frey, 2002; among others). In this work, UV-light is used for the generation of images to detect soft tissues preserved as well as potential specific points for chemical analysis.

This is a first study using a combination of both nondestructive techniques described above for a general examination of the fossil material with taphonomic implications.

\section{The Tlayúa Konservat-Lagerstätte}

Tlayúa quarry is the most important Early Cretaceous (Albian) fossil locality in Mexico, which has been recognized as a Konservat-Lagerstätte locality due the great diversity and abundance of its fossils, the significance of their record in North America, and the exceptional preservation of a large part of its fossils (Alvarado-Ortega and Espinosa-Arrubarrena, 2004; Riquelme, 2009; among others). This fossil locality is an outcrop of the Middle Member of the Tlayúa Formation, which is a sequence of laminated limestones, about 35 meters thick, deposited in a basin of the Western part of the ancient Tethys Sea during the Early Cretacoeus. Today, limestones of the Middle Member of Tlayúa Formation are commercially extracted in the Tlayúa quarry, a small area near Tepexi de Rodríguez, Puebla State, Central Mexico. The sequence in the Tlayúa Quarry includes gray limestones and yellowreddish clay beds. The limestones vary in thickness (1 $\mathrm{mm}$ to $20 \mathrm{~cm}$ ) and they are composed largely of almost pure micrite (98\%-99\% calcium carbonate; see EspinosaArrubarrena and Applegate, 1996). The clay strata are thinner (millimetric) but enriched with iron oxides that produce a characteristic reddish color that emphasizes the layering. The limestone strata yield microfossils, whereas the macrofossils occur within the thin clay strata and they are compressed (Alvarado-Ortega et al., 2007).

The fossil assemblage collected in Tlayúa includes marine and terrestrial invertebrates, vertebrates and plants; nevertheless the best preserved are the vertebrates and among them the fishes have become the symbols of this locality because they are the most diverse and abundant (Espinosa-Arrubarrena and Applegate, 1996; Applegate et al., 2006). Although the authors have been performed diverse palaeometric analyses on a number of fossils from Tlayúa and other Mexican fossiliferous localities (Riquelme, 2009; Riquelme et al., 2009), the aim of the present paper is to provide data on the elemental chemical composition of the fossil material and the lithological matrix of specimens from Tlayúa quarry in order to recognize the possible taphonomic processes and paleoenvironmental conditions that produced the exceptional preservation in this emblematic Lagerstätte. 


\section{Material and methods}

\subsection{Fossil materials}

Two fishes from the National Collection of Paleontology at Instituto de Geología, UNAM, with preserved soft tissues were selected to perform the present analysis:

- IGM 9048, head and abdomen well preserved with vertebrae and ribs disarticulated (this specimen was documented by Alvarado-Ortega et al., 2007, fig. 1 A-C).

- IGM 8026, complete specimen here referred to Unamichthys espinosai Alvarado-Ortega, 2004 (Figure 1).

Because we developed a micromorphological and compositional analyses, the fossils were not exposed to previously demineralized phase and the fossil surface was cleaned only by deionizer water. In this way, chemical pollution from sample preparation is avoided.

\subsection{Analytical approach}

The fluorescence images of the specimens here studied were generated under a 8 Watts UV -light lamp with longwavelength $(365 \mathrm{~nm})$ and short-wavelength $(254 \mathrm{~nm})$. The characterization of the mineral and organic phases on these fossils are based on analysis of 15 selected areas, five regions on IGM 8026 and ten regions in IGM 9048 (see Table 1, Figures 2 and 3). This diagnostic method was implemented for a general examination of the specimen (Figure 1).

The complementary experimental part was developed for the elemental characterization of the fossils by using Particle Induced X-ray Emission spectroscopy (PIXE), which was performed with the $3 \mathrm{MeV}$ Pelletron Tandem Accelerator of the Instituto de Fisica, UNAM. The fossil specimens were irradiated in the selected regions $(1.5 \mathrm{~mm}$ diameter) by a proton external beam in order to produce specific X-ray signals of the elements in the material (Ruvalcaba-Sil, 2008). Under this conditions the analyzed depth is about ten times larger than the electron microprobes (EDS) and its sensitivity may achieve $(\mu \mathrm{g} / \mathrm{g})$-about 100 higher than EDS- from heavier elements (Ruvalcaba-Sil, 2002). PIXE X-ray detectors efficiency was calibrated using standard reference materials of NIST (National Institute of Standard Technology): Buffalo River sediment SRM 2704, Montana sediment SRM 2711, Portland cement SRM 1880a, Bone SRM 1400 and a pellet of $\mathrm{CaCO}_{3}$ Analytic grade by Sigma-Aldrich

\section{Results and discussion}

Images of both samples were generated under UV light as presented above (Figure 2), and their chemical composition was reveled after the PIXE analysis on 15 selected points that included bones, different structures with soft tissues preserved and the rock matrix or fossil bed (Figures 3, 4 and Table 1). The results show the occurrence of some elemental diagnostic fingerprints in these fossils. Trace and major elements, such as Arsenic, Yttrium, Cupper, Nickel, Vanadium, Manganese, Iron, Strontium, Aluminum, Zinc, Silicon, Calcium and Phosphorus, show specific contents for this Lagerstätte (Table 1). A couple of chemical analysis were previously reported by Applegate (1987) and Alvarado-Ortega (2005), which were performed in order to argue on the paleoambiental conditions of the Tlayúa deposit; they found a suitable preparation process for Tlayúa fossils. These authors provided some data on the chemical composition of the reddish clay layers, limestone strata from the Tlayúa quarry and its vertebrate fossils. For the first time, in this paper, we report the presence of

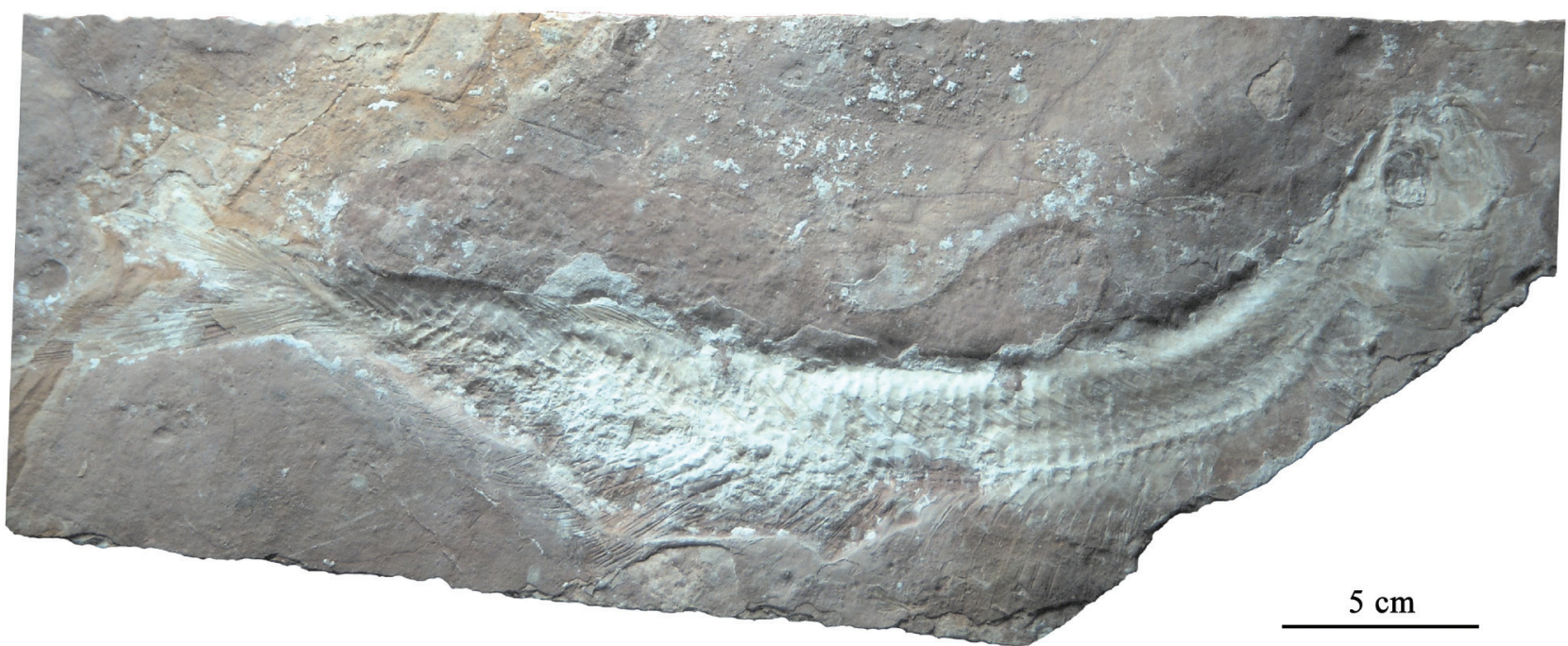

Figure 1. IGM 8026, a Unamichthys espinosai complete specimen from Tlayúa quarry (Early Cretaceous, Albian), at Tepexi de Rodríguez, Puebla, Mexico, as it is seen under natural daylight. 

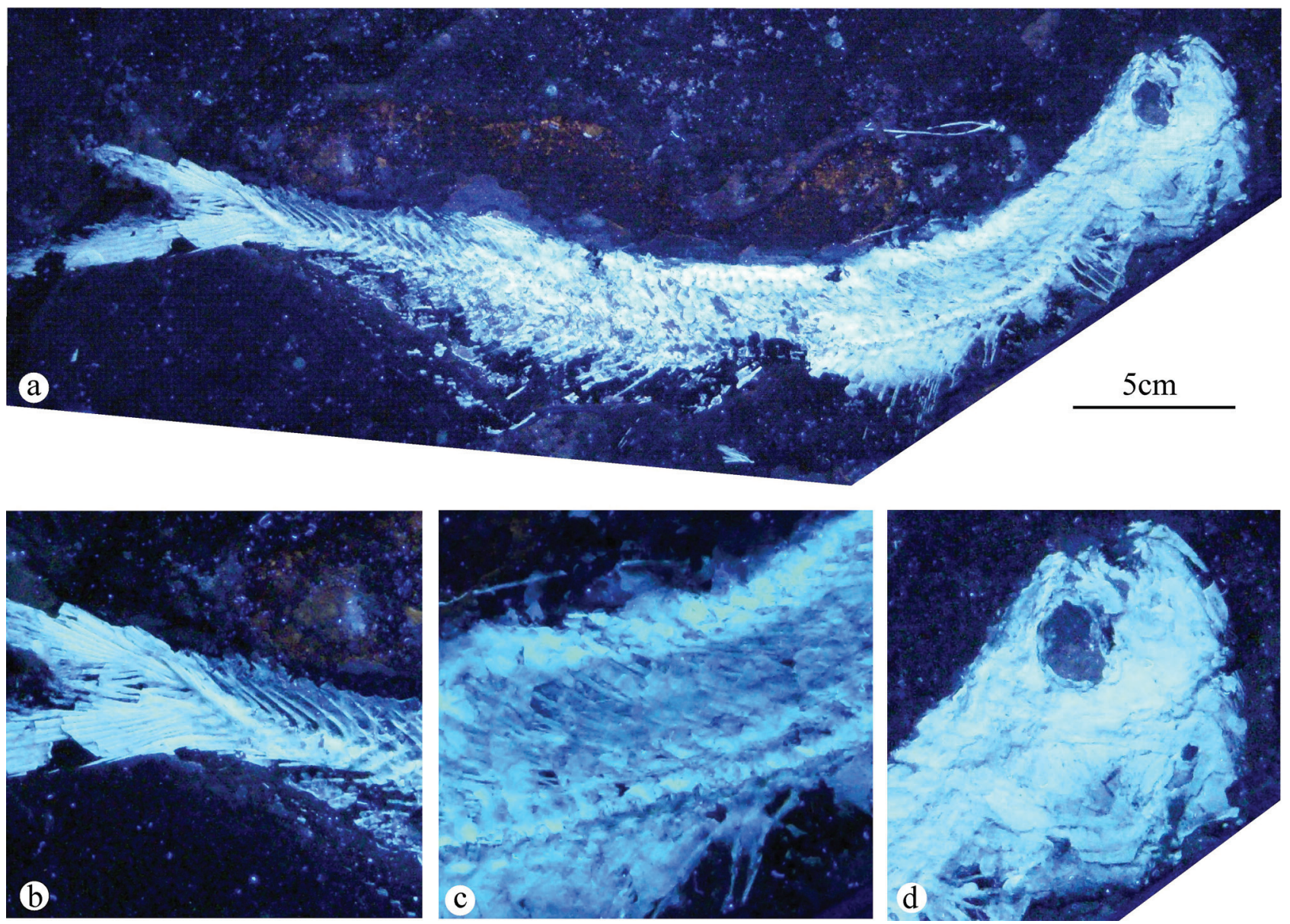

Figure 2. IGM 8026, Unamichthys espinosai complete specimen from Tlayúa quarry (Early Cretaceous, Albian), at Tepexi de Rodríguez, Puebla, Mexico, under $365 \mathrm{~nm}$ UV light. a, Photograph of the visible fluorescence induced by UV of the complete specimen (compare, details against Figure 1 and also note the heterogeneity of the rock). b, Tail (see the overlapping bones in the base of caudal fin). c, Details of the trunk (see the overlaps of scales and the internal bones). d, Details of the head.

Arsenic, Yttrium, Cupper, Nickel, Vanadium, Strontium, Zinc, and Rubidium in rocks and fossils from this Mexican locality (see Table 1 and Figure 4). Calcium, Phosphorus, Manganese, Iron and Arsenic are specific taphonomic indicators for the Tlayúa Lagerstätte, here the preservation vias of soft tissue was recent characterized by a strong activity of biological apatites such as Carbonatoflourapatite and Flourite (Riquelme, 2009). Although it is desirable a detailed discussion about the origin and possible taphonomic implications of each of these elements, the scope of the present work is to provide a preliminary view on the advantages on the use of non-destructive techniques that in this case help us in the detection of these elements. In deposit environments of carbonates, some of the elements mentioned above may contribute to the formation of autigenic minerals and to the transformation of thermodynamically more stables biomacromolecules, for these reason they are biogeochemical indicators that help for the preservations of the remains. Nevertheless, further studies are required to understand their occurrence in Tlayúa fossil and rocks.
In a preliminary discussion, we suggest the taphonomic implication of Arsenic in a fossil deposit such as Tlayúa Quarry. Thus, the presence and dynamic of Arsenic in natural environment occurs for process of weathering, volcanism, hydrothermally and biological activity. Arsenic has a similar behavior to the majority of trace elements, which are strongly absorbed for soil and sediments (De Vitre et al, 1991). For Tlayúa Lagerstätte, it is suggested that Arsenic increments in the fossils may have a primary origin since it may be found in autigenic clays (Montmorillonite, Birnesite and in Goethite, Hematite) and correlated with the organic matter decomposed (Table 1). In other words, it is not related to a geothermal contribution or mineral deposit, (e.g. arsenopirite ores), it is possible that its origin was in the paleo-basin materials, the dynamic of stratification of the water body (oxicline, evaporation, and alkalinity) and the nature of biota. Moreover, Arsenic may have an important taphonomic implication during the diagenetic transformation, since it is a natural concurrent of other anions such as Fluor and Phosphor, so it may be a replacement of these elements in the sedimentary 
Table 1. Multielemental analysis determined by PIXE, $3 \mathrm{MeV}$ proton external beam. Normalized X-rays. Regions analyzed 0-8 in specimen IGM 9048 , 9 in standard bone, and 103-109 in specimen IGM 8026 (also see Figures 3 and 4).

\begin{tabular}{|c|c|c|c|c|c|c|c|c|c|c|}
\hline & Analized points & $\mathrm{Al}$ & As & $\mathrm{Ca}$ & $\mathrm{Cu}$ & $\mathrm{Fe}$ & K & $\mathrm{Mn}$ & $\mathrm{Ni}$ & $\mathrm{P}$ \\
\hline 103 & Soft Tissue Abdomen & & 0.0090 & 0.7860 & 0.0072 & 0.0184 & & 0.0031 & 0.0066 & 0.1007 \\
\hline 104 & Soft Tissue Abdomen & & 0.0073 & 0.7561 & 0.0049 & 0.0083 & & 0.0022 & 0.0047 & 0.1452 \\
\hline 105 & Anal fin & & 0.0074 & 0.7469 & 0.0067 & 0.0050 & & 0.0017 & 0.0054 & 0.1494 \\
\hline 106 & Ocular cavity & 0.0024 & 0.0010 & 0.8470 & 0.0026 & 0.1021 & & 0.0059 & 0.0104 & 0.0117 \\
\hline 107 & Opercle & & 0.0091 & 0.7417 & 0.0070 & 0.0102 & & 0.0016 & 0.0065 & 0.1434 \\
\hline 108 & Fossil bed & 0.0105 & 0.0025 & 0.2957 & 0.0011 & 0.5404 & 0.0409 & 0.0053 & 0.0032 & 0.0019 \\
\hline 109 & Caudal fin & & 0.0052 & 0.8189 & 0.0043 & 0.0356 & & 0.0045 & 0.0065 & 0.0755 \\
\hline 0 & Opercle & & 0.0085 & 0.4554 & 0.0384 & 0.2579 & & & & 0.0991 \\
\hline 1 & Fossil bed & & 0.0009 & 0.7583 & 0.0216 & 0.1689 & & & & \\
\hline 2 & Soft Tissue Abdomen & 0.0052 & 0.0056 & 0.3955 & 0.0147 & 0.3939 & 0.0091 & & & 0.0818 \\
\hline 3 & Soft Tissue Abdomen & & 0.0012 & 0.7550 & 0.0334 & 0.1006 & & 0.0075 & & 0.0597 \\
\hline 4 & Soft Tissue Abdomen & & 0.0011 & 0.0681 & 0.0564 & 0.2576 & & 0.0059 & & 0.0088 \\
\hline 5 & Soft Tissue Pelvic zone & & 0.0061 & 0.5602 & 0.0219 & 0.1806 & & 0.0029 & & 0.1315 \\
\hline 6 & Soft Tissue Pelvic zone & & 0.0086 & 0.6097 & 0.0286 & 0.0887 & & 0.0010 & & 0.1528 \\
\hline 7 & Fossil bed & 0.0093 & 0.0020 & 0.1221 & 0.0038 & 0.7152 & 0.0121 & 0.0011 & 0.0035 & 0.0017 \\
\hline \multirow[t]{2}{*}{8} & Fossil bed & 0.0044 & 0.0014 & 0.5066 & 0.0103 & 0.3853 & 0.0093 & 0.0019 & 0.0012 & 0.0038 \\
\hline & Reference/Bone & & & 0.4547 & 0.0161 & 0.2837 & & & & 0.1575 \\
\hline
\end{tabular}

\begin{tabular}{|c|c|c|c|c|c|c|c|c|c|}
\hline & Analized points & $\mathrm{Rb}$ & S & $\mathrm{Si}$ & $\mathrm{Sr}$ & $\mathrm{Ti}$ & V & $\mathrm{Y}$ & $\mathrm{Zn}$ \\
\hline 103 & Soft Tissue Abdomen & & 0.0118 & 0.0063 & 0.0425 & & & 0.0015 & 0.0071 \\
\hline 104 & Soft Tissue Abdomen & & 0.0197 & 0.0063 & 0.0380 & & & 0.0011 & 0.0062 \\
\hline 105 & Anal fin & & 0.0206 & 0.0067 & 0.0417 & & & 0.0012 & 0.0074 \\
\hline 106 & Ocular cavity & & & 0.0036 & 0.0069 & & & & 0.0064 \\
\hline 107 & Opercle & & 0.0188 & & 0.0473 & & & 0.0017 & 0.0126 \\
\hline 108 & Fossil bed & 0.0007 & & 0.0921 & 0.0012 & & & & 0.0035 \\
\hline 109 & Caudal fin & & 0.0104 & 0.0039 & 0.0279 & & & 0.0009 & 0.0064 \\
\hline 0 & Opercle & & 0.0203 & 0.0282 & 0.0617 & & & & 0.0306 \\
\hline 1 & Fossil bed & & 0.0057 & 0.0280 & 0.0132 & & & & 0.0034 \\
\hline 2 & Soft Tissue Abdomen & & 0.0093 & 0.0430 & 0.0308 & & 0.0040 & & 0.0072 \\
\hline 3 & Soft Tissue Abdomen & & & & 0.0362 & & & & 0.0064 \\
\hline 4 & Soft Tissue Abdomen & & & 0.5824 & 0.0054 & & 0.0049 & & 0.0094 \\
\hline 5 & Soft Tissue Pelvic zone & & 0.0125 & 0.0173 & 0.0595 & & 0.0016 & & 0.0059 \\
\hline 6 & Soft Tissue Pelvic zone & & 0.0223 & 0.0212 & 0.0586 & & 0.0014 & & 0.0070 \\
\hline 7 & Fossil bed & & & 0.1251 & 0.0009 & 0.0005 & & & 0.0026 \\
\hline \multirow[t]{2}{*}{8} & Fossil bed & & 0.0043 & 0.0614 & 0.0064 & 0.0009 & & & 0.0028 \\
\hline & Reference/Bone & & & & 0.0089 & & & & 0.0792 \\
\hline
\end{tabular}

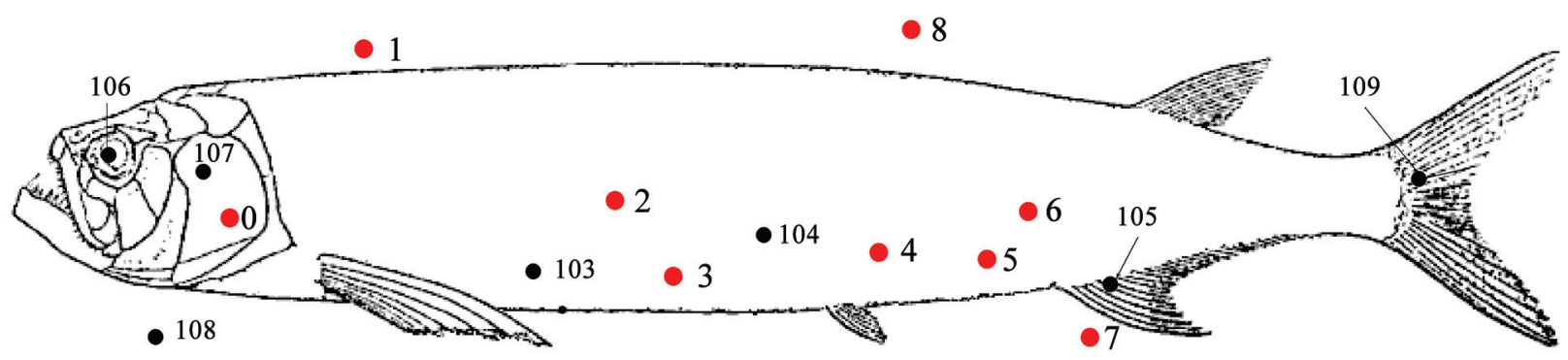

Figure 3. Regions analyzed by PIXE on the fossil, points 0-8 in specimen IGM 9048, 103-109 in specimen IGM 8026 (also see Table 1 and Figure 4). 


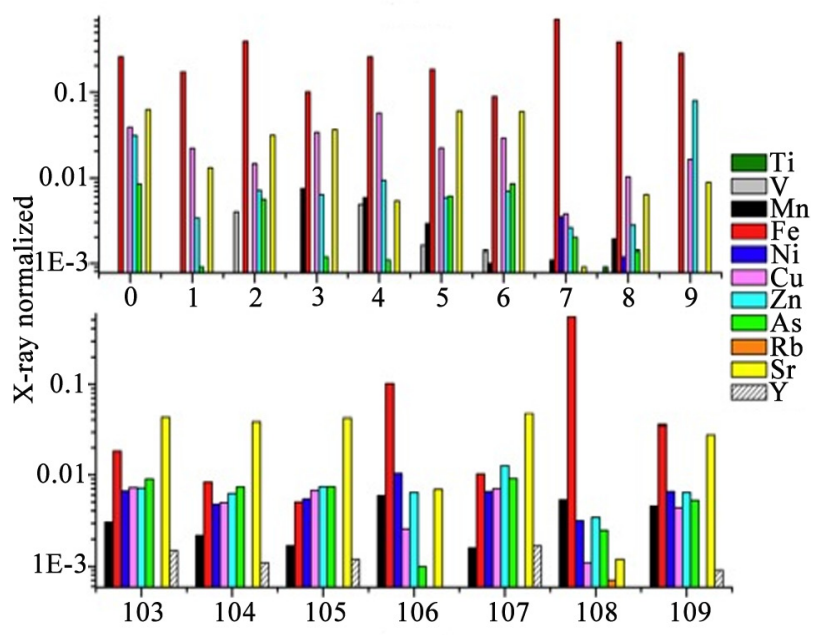

Figure 4. Particular trace elements after PIXE analysis. 0-8 in IGM 9048, 9 in standard bone, 103-109 in IGM 8026 (also see Table 1 and Figure 3).

apatites molecules, such as Fluorapatite and CarbonatedFluorapatite. These molecules are such significant for soft tissue preservation (Lucas and Prèvôt, 1991).

\section{Conclusions}

PIXE is a suitable technique for elemental analysis of fossils, because have non-destructive features and high sensitive elemental detection in specific regions. Traces and major elements in each area and tissues of the fossils and beds can be obtained quickly (few minutes) without damage.

Visible Fluorescence Induced by the UV-Light is an important tool for a quick diagnostic examination, in order to determinate a preliminary morphological structures and differences in the chemical composition of the specimen and the fossil bed. Under UV emission a particular colour pattern occurs, produced by both organic and mineral phase (Purewal et al., 2008), besides the organic phase tends to be more fluorescent than mineral. Therefore, every tone of color means a different chemical composition in a fossil sample. The fluorescence light emission changes as a function of the remains of organic structures preserved soft tissue, as well as mineral phases in the fossils Although the fluorescence of fossil material is well-known by Paleontology, we use this natural property for understand preservation mechanisms of soft tissue, correlated to fossil fingerprints (chemical traces) with exceptional preservation.

This is a first study using UV-Light and PIXE as a nondestructive methodology for a general examination of the fossil specimen (Figure 1). With these group of diagnostic and quantitative analysis, it is possible to determinate the biogeochemistry behaviour of soft-tissues preservation and original mineralogy of fossil bed in Tlayúa Lagerstätte, occurrence under unique chemistry, sedimentary and biological conditions.

Finally, Palaeometry is a new concept which tends to gather several non-destructive techniques employed recently in Paleontology but in a disperse way.

\section{Acknowledgments}

This paper was possible thanks to the daily effort of Aranguthy family and their Tlayúa quarry workers. M.C. Perrilliat generously arranged the loan of the fossil material. Authors thank to K. López and F. Jaimes for the IF-UNAM Pelletron accelerator operation. This research was supported by UNAM grant PAPIIT IN225008 and partially by CONACyT grand U49838-R.

\section{References}

Alvarado-Ortega, J., 2004, Description and relationships of a new ichthyodectiform fish from the Tlayúa Formation, Puebla, Mexico: Journal of Vertebrate Paleontology, 24(4), 802-813.

Alvarado-Ortega, J., 2005, Sistemática de los peces Ichthyodectiformes de la Cantera Tlayúa, Puebla, México: D.F., México, Universidad Nacional Autónoma de México, Instituto de Geología, Tesis de Doctorado, $308 \mathrm{p}$.

Alvarado-Ortega J., Espinosa-Arrubarrena, L., 2004, Conservación de tejidos blandos en los fósiles de la Cantera Tlayúa: IX Congreso Nacional de Paleontología. Sociedad Mexicana de Paleontología, Tuxtla Gutiérrez, Chiapas, Libro de resúmenes p.16.

Alvarado-Ortega, J., Espinosa-Arrubarrena, L., Blanco-Piñón, A., Vega, F., Benammi M., Briggs, D.E.G., 2007, Exceptional preservation of the soft tissues in fishes from Tlayúa Quarry, Central Mexico: Palaios, 22(6), 682-685.

Applegate, S.P., 1987, A preliminary study of the Tlayúa Quarry near Tepexi de Rodríguez, Puebla: Sociedad Mexicana de Paleontología, $1,40-50$.

Applegate, S. P., Espinosa-Arrubarrena, L., Alvarado-Ortega, J., Benammi, M., 2006, Revision of Recent Investigations in the Tlayúa Quarry: pp 276-304, in: Vega, F.J., Nyborg, T.G., Perrilliat, M.C., MontellanoBallesteros, M., Cevallos-Ferriz. S.R.S., Quiroz-Barroso, S.A. (eds.), Studies on Mexican Paleontology, Topics on Geobiology, v. 24, 326 pp. Springer, Dordrecht, The Netherlands.

Briggs D.E.G., 2003, The role of decay and mineralization in the preservation of soft-bodied fossils: Annual Review of Earth Planet Sciences, 31, 275-301.

Buzit-Tragni C., 2005, The Use of ultraviolet-Induced Visible Fluorescence for examination of photographs: 3rd Cycle Thesis, Advanced Residency Program in Photograph Conservation, Rochester Institute of Technology, New York.

De Vitre, R., Belzile, N., Tessier, A., 1991, Speciation and adsorption of arsenic on diagenetic iron oxyhydroxides: Limnolology and Oceanography, 36, 1480-1485.

Espinosa-Arrubarrena, L., Applegate, S.P., 1996, A possible model for the paleoecology of the vertebrate bearing beds in the Tlayúa quarries, near Tepexi de Rodríguez, Puebla, México, in Arratia, G., and Viohl, G., eds., Mesozoic Fishes-Systematics and Paleoecology: Verlag Dr. Friedrich Pfeil, Munich, p. 539-550.

Johansson, S.A.E., Campbell J.L., Malmqvist, K.G., 1995, Particle-Induced X-ray Emission Spectrometry (PIXE). Chemical Analysis: Series of monograph on analytical chemistry and its applications, vol. 133, J.D. Widefrodner series ed., John Wiley \& Sons, New York.

Lucas, J., Prèvôt, L.E., 1991, Phosphates and Fossil Preservation: pp. 389405, in: Allison, P.A., Briggs, D.E.G. (eds.), Taphonomy. Releasing the Data Locked in the Fossil Record. Plenum Press. New York. 
Peterson P.J., Summons R.E., Donnoghue, P.J., 2007, Molecular Palaeobiology: Palaeontology, 50(4), 775-809.

Purewal, V., Colston, B., Röhrs, S., 2008, Developing a simple screening method for the identification of historic biocide residues on herbarium material in museum collections: X-Ray Espectometry, $37,137-141$.

Raffa, E.C., Schollaerta K.L., Nelsona, D.E., Donoghuec, Ph. C.J., Thomasc, C.-W., Turnera, F.R., Steina, B.D., Dongd, X., Bengtsone, S., Huldtgrene, T., Stampanonig, F,M., Chongyui, Y., Raffa, R.A., 2008, Embryo fossilization is a biological process mediated by microbial biofilms: Proceedings of the National Academy of Sciences of the United States of America, 105(49), 19359-19364.

Riquelme, F., 2009, Paleontología molecular: Preservación excepcional de tejidos no-mineralizados fósiles del Cretácico temprano (Albiano) de la Cantera Tlayúa, una Konservat-Lagerstätte de Puebla, México: México, Facultad de Ciencias, Universidad Nacional Autónoma de México, Tesis de Licenciatura.

Riquelme, F., Ruvalcaba-Sil, J.L., Alvarado-Ortega, J., 2009, Paleometría: Uso de técnicas de haces de iones en el análisis de indicadores biogeoquímicos involucrados en la preservación fósil: XII Congreso Nacional de Paleontología, Centro de Geociencias, Campus UNAM-Juriquilla, Queretaro, 25-27 de febrero del 2009. Libro de Resúmenes, p. 21.
Ruvalcaba-Sil, J.L., 2002, PIXE, RBS y PIGE: Técnicas de origen nuclear aplicadas a la arqueozología: pp. 129-151, In: ArroyoCabrales, J.E., Corona M. (eds.), Relaciones hombre-fauna: una zona interdisciplinaria de estudio: CONACULTA, INAH. México.

Ruvalcaba-Sil, J.L., 2008, Las técnicas de origen nuclear: PIXE y RBS, In M.A. del Egido y T. Calderón, coords, La Ciencia y el Arte, Instituto del Patrimonio Histórico Español: IPHE-CSIC, Madrid, 151-172.

Tischlinger, H., Frey, E., 2002, Ein Rhamphorhynchus (Pterosauria, Reptilia) mit ungewöhnlicher Flughauterhaltung aus dem Solnhofener Plattenkalk: Archaeopteryx, 20, 1-20.

Tsuji, K., Jasna, I., Grieken, R., 2004, X-ray Spectrometry: Recent Technological Advances, John Wiley and Sons, NY.

Manuscript received: February 27, 2009.

Corrected manuscript received: June 5, 2009.

Manuscript accepted: June 10, 2009. 